\title{
同時購買買物行動モデルによる小売施設の立地分析 LOCATIONAL ANALYSIS OF RETAIL FACILITIES BY A MULTI-PURPOSE SHOPPING BEHAVIOR MODEL
}

\author{
孫 相 洛*, 谷村 秀彦**, 歳 森 敦*** \\ Sangrag SON, Hidehiko TANIMURA and Atsushi TOSHIMORI
}

This paper analyzes how the shopping behavior of consumers influences upon retail facility location within the context of multi-purpose shopping. We make a model of optimal frequencies of single- and multi-purpose trips and derive the degree of multi-purpose shopping from it. It is shown that consumers' spatial behavior is a function of their locations relative to retail facilities. This analysis is then utilized as an input to the profit-maximizing equation of retailers. The model is illustrated through the use of numerical analysis.

Keywords : consumer shopping behavior, multi-purpose shopping, retail facility location.

消費者行動，同時購買，小売施設立地

\section{1.はじめに}

\section{1 研究の目的}

小売商業の経済活動は，施設に出向いてきた不特定多 数の消費者に財やサービスを提供し，利潤を得ることに よって成り立つので，小売施設は消費者があってはじめ て成立する経済主体である。従って, 消費者の買物行動 パターンとその変化が施設側に影響を及ぼしていると考 えられる。本研究では消費者の買物行動における買物場 所選択行動の側面から小売施設の立地行動及びその空間 構造を考察する。

この観点から, 消費者は居住地からの最近隣中心地 $($ 施 設）への個別購買トリップのみを行うと想定し, 小売業 のような中心機能の立地及びその空間構造を説明するモ デルが従来の中心地モデルである1。しかし，実際には消 費者は買物費用を最小にするために行動しており，なお 消費者側の変化により個別購買と同時購買トリップを組 み合わせたトリップパターン (mixed shopping trip pattern）を行っている。すなわち，消費者の一連の買物
スケジュールに従い, 高次商品の購入のために高次中心 地に出掛けた際, 可能な限り低次商品もある程度買い(同 時購買)，その残りは最近隣低次中心地で購入し(個別購 買）消費する。

施設立地に影響を及ぼす消費者の買物行動の中でも， 特に同時購買の買物行動の重要性はよく知られており (Hanson, 1980; O’Kelly, 1981；日経産業消費研究所, 1993）吕消費者にとっては同時購買トリップによって範 囲の経済 (scope economies) ${ }^{3)}$ の効果を得るので，買物 費用を節減することができ, 現実的な買物行動パターン である。そこで, 個別購買トリップのみの買物行動仮定 に比へ，個別購買と同時購買の組み合わせのトリップパ ターンを考えることにより, 現実の小売施設空間構造の 形成メカニズムをより正しく識別することができると思 われる。このような一連の買物行動パターシは地域にお ける中心地の空間的分布に対する消費者の相对的な位置 によって異なると考えられる。

従って, 本研究は, 消費者は買物費用を節約するため
* 筑波大学社会工学研究科 大学院生・博士 (都市・地域計画)

** 筑波大学社会工学系 教授·工博

*** 図書館情報大学 助手・修士(都市・地域計 画)
Graduate Student, Urban and Regional Planning, Doctoral Program in Socio-Economic planning, Univ. of Tsukuba, M. Eng., Ph. D.

Prof., Institute of Socio-Economic Planning, Univ. of Tsukuba, Dr. Eng.

Research Associate, Univ. of Library and Information Science, M. Sc. 
に個別購買と同時購買のトリップを組み合わせるトリッ プパターンを行い，かつそれは中心地の空間的分布に対 する消費者の位置によって異なると考える。そのような 買物行動が小売施設の立地行動にどのような影響を与 え，その結果としての小売施設空間構造はどのようなも のになるかを理論的に明らかにすることを目的とする。

\section{2 既往研究と本研究の位置付け}

小壳業を始めとする中心地機能の分析に基本的な枠組 を与えた中心地理論では，消費者行動を最近隣施設への 個別購買として想定しているが(林，1986, pp.531-564), 現実的には「個別購買十同時購買」のトリップパターン を行っている。

Hotelling (1929) の二人の行商人の競争的立地選択行 動の分析においては，消費者は一つの同質商品の一単位 を需要し，商品費用と交通費用の合計が最小となる施設 を選択する。その際，施設は利益を最大化するために線 形市場において最終的にはセンターに集中立地する均衡 状態に行き着くとされている。このモデルでは1トリッ プに 1 単位の商品を購入し, かつ交通費用は移動距離の みに比例すると考えられているので，規模の経済 (scale economies）と範囲の経済（scope economies）の効果が 排除されている。従って，本研究の立場から見れば，個 別購買のみを扱ったモデルであるといえる。

一方，Eaton and Lipsey（1982）は高次と低次の $2 つ$ の中心地を仮定し，高次財と低次財の同時購買行動に よって高次中心地に対する施設の集積が起きることを示 した。Thill（1992）は，消費者は商品費用と交通費用の 合計が最小となるように行動すると考え，それに応じた 施設の立地行動を考察した。彼は，消費者の同時購買の 買物が多くなればなるほど低次施設のみの中心地は高次 中心地（高次と低次施設の集積地）の方へ移動するが， 完全には一体とはならず，空間競争の遠心力（centrifugal force) と同時購買行動の求心力 (centripetal force) とのトレード・オフによって均衡立地が行われるとした。

この両研究は異なる階次商品に対する既知の頻度から 消費者の同時購買率を導いている。結局，同時購買の買 物行動特性を表すパラメー夕を外生的に与えており，全 ての消費者の買物行動特性は同じであることを前提とし ている。

Bacon (1984) は単一中心地と複数中心地，そして単一 商品と複数商品の場合をとりあげ，それぞれの組み合わ せケースにおいて，商品費用・交通費用・販蔵費用の合 計が最小になるように行動する消費者の空間的買物行動 特性を多様な側面より考察している。結局，彼の研究は 消費者の買物行動特性を表すパラメー夕を内生的に導い ているものの，消費者行動，かつ個別購買行動に重点を 置いたもので，小売施設の立地行動を扱っていない。し かし，本来生産者の在庫の貯蔵により負担する貯蔵費用
の概念を消費者の買物行動に適用している。その考え方 を本研究の同時購買の買物行動の場合においての貯蔵費 用のベースとして用いる。

以上のように, 既往の研究の多くは, 消費者の買物行 動特性を表すパラメー夕を外生的に与えており，かつ空 間的に変化しないと考え, 同時購買率が高くなると低次 施設は空間的に集積するとの結果を得ている。それは, 消費者の買物行動特性が空間的に異なることを考虑しな かったことによる結果である。しかし，地域において全 ての消費者にとって少なくとも交通費用は異なるので, トリップパターン及び同時購買率も異なるのが当然であ ろう。従って, 消費者の買物行動特性は中心地の空間的 分布に对する消費者の位置によって異なると考之た場 合，前述のような低次施設の立地行動が常に有利である かは検討の余地があり，小売施設の空間構造はそれとは 違った結果が得られると子想される。すなわち，本研究 では消費者の買物行動が個別購買十同時購買」のトリッ プパターンであることを想定しており，トリップ頻度・ 同時購買率は消費者の位置から内生的に求められる。

研究の手続きとしては以下のように進める。2 章では 消費者の買物行動に関する仮定に従い,「同時購買買物行 動モデル」を構築し，3 章では消費者の空間的買物行動 特性を定式化する。 4 章では施設の商圈境界を設定し， 商圈ごとの販売額の数式を算出する。それを用いて， 5 章では小売施設の立地行動と空間構造について数值シ ミュレーションを行う。

\section{2．消費者の買物行動とモデル定式化}

\section{1 仮定設定}

（1）消費者は費用が最小となるように買物行動を行う。 モデルの目的関数は「買物費用最小化」である。

(2) 消費者の買物費用は, 商品費用・交通費用・貯蔵費 用の合計である。

(3) 消費者は低次財 $Q_{1}$ 単位と高次財 $Q_{2}$ 単位を消費し, これらは価格に非弾力的 (inelastic) である。

(4) 市場には低次財のみを供給する低次中心地 $C_{L}$ と, 低次財と高次財の両方を供給する高次中心地 $C_{H}$ があ る。消費者は $C_{L}$ 又は $C_{H}$ で低次財のみを購入する個 別購買と, $C_{H}$ で低次財と高次財を同時に購入する同 時購買の二種類の買物トリップを行う。

(5) 財の価格は外生的であり，低次中心地と高次中心地 の低次財の価格は等しい。

(6) 交通費用は各中心地 (低次 1 , 高次 2 ) への距離 $d_{1}$, $d_{2}$ と, 買物トリップの頻度 $f_{1}, f_{2}$ に比例して増加する。 交通費用はこれと購買所要時間のみで定まる。低次財 と高次財の購買所要時間費用を各々 $x_{1}, x_{2}$ で示す。 従って, 個別購買トリップによる購買所要時間費用は $x_{1}$, 同時購買のそれは $x_{1}+x_{2}$ となる。 


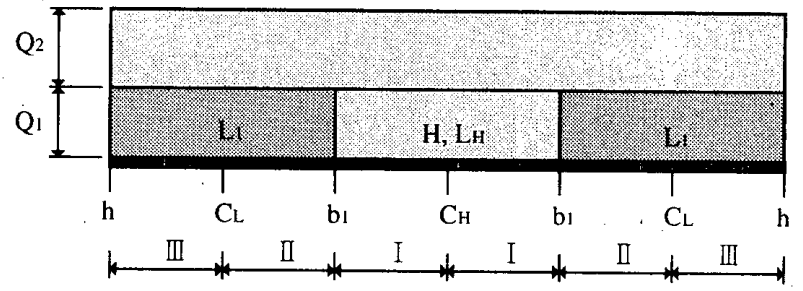

図 1 仮想の小売施設空間構造

(7) 財は時間に対して一定の比率で消費される。

(8) 問題を取り扱いやすくするために, 同じ財について の一回の買物トリップ当たりの購買量は等しいと仮定 する。すなわち，一回の個別購買トリップにおける低 次財の購買量と一回の同時購買トリップにおける低次 財の購買量は等しい。また, 財の貯蔵量が 0 にならな ければ，買物トリップは行われない。

(9) 貯蔵費用は貯蔵（保有）されている財の価格のみに 比例して増加する。販蔵量が 0 の時点での貯蔵費用は 0 と見なす。

(10) 対象空間システムは線形かつ対称で, 高次中心地と 低次中心地は図 1 のように配置されている4)。

(11) 消費者は空間上に一様分布している。

\section{2 使用变数及び記号の定義}

$Q_{1}, Q_{2}$ : 各消費者（家計）のある一定期間中の低次商品 (1)と高次商品 $(2) の$ 需要量。

$p_{1}, p_{2}$ ：各々低次商品と高次商品の単位当たり価格。 $s_{1}, s_{2}$ : 全期間において消費者が保有している低次商品 と高次商品の単位当たり貯蔵費用(例えば, $s_{1}=$ 0.1 は商品価格の $10 \%$ が貯蔵費用になることを 意味する)。

$k$ : 単位距離当たり移動費用。

$d_{1}, d_{2}$ : それぞれ消費者の居住地から最近隣の低次中心 地 $C_{L}$ と高次中心地 $C_{H}$ までの距離 $\left(d_{1} \leq d_{2}\right)$ 。

$x_{1}, x_{2}$ : それぞれ低次商品と高次商品の購入に要する購 買所要時間費用（search costs）。

$t_{1}, t_{2}$ : それぞれ個別購買と同時購買の買物卜リップの $($ 移動費用 $)+\left(\right.$ 購買所要時間費用)。 $t_{1}=2 k d_{1}$ $+x_{1}, t_{2}=2 k d_{2}+x_{1}+x_{2}$ となる $\left(t_{1}<t_{2}\right) 。$

$f_{1}, f_{2}$ : それぞれ一定期間中の消費者の個別購買と同時 購買の買物トリップの頻度 $\left(f_{1} \geq 0, f_{2}>0\right)$ 。

$r:$ 一定期間の低次商品の需要量の中で, 高次中心 地への同時購買トリップの際に，同時購買され る低次商品量の比率 (同時購買率, $0<r \leqq 1, r$ $\left.=f_{1} /\left(f_{1}+f_{2}\right)\right)$ 。

$\rho$ : 人口密度（単位距離当たり人口）。

\section{3 モデル定式化}

消費者は買物費用最小化の行動規範に基づいて行動し ており，個別購買と同時購買トリップの組み合わせのト リップパターンを行っている。その同時購買トリップに
より範囲の経済の効果を得る。

このような一連の買物行動において，消費者が負担す る買物費用の構成要素として商品費用・交通費用・貯蔵 費用を考慮する。高いトリップ頻度は交通費用を増加さ せるが, 貯蔵費用を減少させるとの関係がある。そこで, 消費者はこれらの諸費用の間のトレード・オフによって 買物の全体費用 $(S C)$ を最小にするトリップ頻度を選択 する。従って，買物費用最小化の「同時購買買物行動乇 デル」は式(1)のように表すことができる。

Minimize $S C=\left\{p_{1} Q_{1}+p_{2} Q_{2}\right\}$

$$
\begin{aligned}
f_{1}, f_{2} & +\left\{\left(2 k d_{1}+x_{1}\right) f_{1}+\left(2 k d_{2}+x_{1}+x_{2}\right) f_{2}\right\} \\
& +\frac{1}{2}\left\{\frac{s_{1} p_{1} Q_{1}}{f_{1}+f_{2}}+\frac{s_{2} p_{2} Q_{2}}{f_{2}}\right\}
\end{aligned}
$$

式(1)の第 1 項は低次と高次の商品費用，第 2 項は低次 および高次中心地への交通費用，第 3 項は低次商品と高 次商品の貯蔵費用5である。

\section{3．消費者の買物行動}

\section{1 消費者の買物行動特性}

消費者の買物費用を最小にする最適トリップパターン の各パラメータ $\left(f_{1}, f_{2}\right)$ をモデル(1)から内生的に求める。 $f_{1}, f_{2}$ について 1 階の導関数を求めそれらを連立方程式 として解けば，低次商品の購入のための個別購買トリッ プと, 低次商品と高次商品の同時購入のための同時購買 トリップの最適頻度 $\left(f_{1}^{*}, f_{2}^{*}\right)$ が得られる。

$$
\begin{aligned}
& f_{2}^{*}=\sqrt{\frac{s_{2} p_{2} Q_{2}}{2\left(t_{2}-t_{1}\right)}} \\
& f_{1}^{*}=\sqrt{\frac{s_{1} p_{1} Q_{1}}{2 t_{1}}}-\sqrt{\frac{s_{2} p_{2} Q_{2}}{2\left(t_{2}-t_{1}\right)}}=\sqrt{\frac{s_{1} p_{1} Q_{1}}{2 t_{1}}}-f_{2}^{*}
\end{aligned}
$$

一方，同時購買率 $(r)$ は式(4)のように定義することが できるので，それに式(2)，(3)を代入すればよい。

$$
\begin{aligned}
& r=\frac{f_{2}}{f_{1}+f_{2}} \\
& r^{*}=\sqrt{\frac{s_{2} p_{2} Q_{2} t_{1}}{s_{1} p_{1} Q_{1}\left(t_{2}-t_{1}\right)}}=\sqrt{\frac{s_{2} p_{2} Q_{2}}{s_{1} p_{1} Q_{1}}} \sqrt{\frac{t_{1}}{t_{2}-t_{1}}}
\end{aligned}
$$

式(5)において，他の条件 $\left(t_{1} /\left(t_{2}-t_{1}\right)\right)$ が一定ならば, 高次商品（例之ば，耐久財）に比べ低次商品（食料品な どの消費財）の貯蔵費用が相対的に低くなると，同時購 買率は増加する。しかし，低次商品の貯蔵が容易ではな く費用が高ければ，近くの低次中心地から低次商品を頻 繁に購入するようになる(同時購買率が低い)。一方，高 次商品と低次商品の貯蔵費用が一定であるとすれば，低 次中心地までの移動費用の減少よりも，高次中心地への 移動費用と低次中心地への移動費用との差の減少が大き いと $\left(\nabla t_{1}<\nabla\left(t_{2}-t_{1}\right)\right)$, 同時購買率は増加する。言い換之 れば, 交通費用が安価になり移動性が増大すれば $\left(t_{1}\right.$ より $t_{2}$ の相対的低下を意味), 遠距離移動が容易になるので, 同時購買率は增加する。 
以上の同時購買と個別購買のトリップ頻度 ・同時購買 率の式(2)，(3)，(5)を，仮想地域（図 1) において中心地 の空間的分布に対し消費者の相対的な位置を考慮し，便 宜上, 次のように変形しておく6)。但し $, b_{1}, C_{L}, h, d_{1}$, $d_{2}$ は高次中心地 $C_{H}$ （原点 $=0 ）$ から離れた距離の地点を 示す。

(1) 地区 I $\left[C_{H}, b_{1}\right]$ のトリップパターン

この地区の消費者の個別購買と同時購買トリップの目 的地は $C_{H}$ で，その移動距離は同じであるので, $d_{1}=d_{2}$, $t_{1}=2 k d_{2}+x_{1}, t_{2}=2 k d_{2}+x_{1}+x_{2},\left(t_{2}-t_{1}\right)=x_{2}$ となる。こ れらを式(2)，(3)，(5)に代入すれば，当地区の消費者の買 物費用最小化のトリップパターンが得られる。

$$
\begin{aligned}
& f_{2}^{*}=\sqrt{\frac{s_{2} p_{2} Q_{2}}{2 x_{2}}} \\
& f_{1}^{*}=\sqrt{\frac{s_{1} p_{1} Q_{1}}{2\left(2 k d_{2}+x_{1}\right)}}-\sqrt{\frac{s_{2} p_{2} Q_{2}}{2 x_{2}}} \\
& r^{*}=\sqrt{\frac{s_{2} p_{2} Q_{2}\left(2 k d_{2}+x_{1}\right)}{s_{1} p_{1} Q_{1} x_{2}}}
\end{aligned}
$$

式(6)，(7)を式(1)に入れると，最適トリップパターンに よってこの地区の消費者が負担する買物費用が得られ る。

$$
S C^{*}=\left(p_{1} Q_{1}+p_{2} Q_{2}\right)+\sqrt{2 s_{1} p_{1} Q_{1}\left(2 k d_{2}+x_{1}\right)+2 s_{2} p_{2} Q_{2} x_{2}}
$$

(2) 地区 II $\left[b_{1}, C_{L}\right]$ のトリップパターン

個別購買の目的地は $C_{L}$, 同時購買のそれは $C_{H}$ となる ので, $d_{1}=\left(C_{L}-d_{2}\right), t_{1}=2 k\left(C_{L}-d_{2}\right)+x_{1}, t_{2}=2 k d_{2}+x_{1}$ $+x_{2}$ であり, $\left(t_{2}-t_{1}\right)=2 k\left(2 d_{2}-C_{L}\right)+x_{2}$ となる。

$$
\begin{aligned}
& f_{2}^{*}=\sqrt{\frac{s_{2} p_{2} Q_{2}}{2\left\{2 k\left(2 d_{2}-C_{L}\right)+x_{2}\right\}}} \\
& f_{1}^{*}=\sqrt{\frac{s_{1} p_{1} Q_{1}}{2\left\{2 k\left(C_{L}-d_{2}\right)+x_{1}\right\}}}-\sqrt{\frac{s_{2} p_{2} Q_{2}}{2\left\{2 k\left(2 d_{2}-C_{L}\right)+x_{2}\right\}}} \\
& r^{*}=\sqrt{\frac{s_{2} p_{2} Q_{2}\left\{2 k\left(C_{L}-d_{2}\right)+x_{1}\right\}}{s_{1} p_{1} Q_{1}\left\{2 k\left(2 d_{2}-C_{L}\right)+x_{2}\right\}}} \\
& S C^{*}=\left(p_{1} Q_{1}+p_{2} Q_{2}\right) \\
& +\sqrt{2 s_{1} p_{1} Q_{1}\left\{2 k\left(C_{L}-d_{2}\right)+x_{1}\right\}+2 s_{2} p_{2} Q_{2}\left\{2 k\left(2 d_{2}-C_{L}\right)+x_{2}\right\}}
\end{aligned}
$$

(3) 地区III $\left[C_{L}, h\right]$ のトリップパターン

当地区の消費者の個別購買と同時購買トリップの目的 地はそれぞれ $C_{L}, C_{H}$ で，移動方向が同じである。した がって, $d_{1}=\left(d_{2}-C_{L}\right), t_{1}=2 k\left(d_{2}-C_{L}\right)+x_{1}, t_{2}=2 k d_{2}+x_{1}$ $+x_{2}, \quad\left(t_{2}-t_{1}\right)=2 k C_{L}+x_{2}$ で, $f_{2}^{*}, f_{1}^{*}, r^{*}$ は以下のよj になる。

$$
\begin{aligned}
& f_{2}^{*}=\sqrt{\frac{s_{2} p_{2} Q_{2}}{2\left(2 k C_{L}+x_{2}\right)}} \\
& f_{1}^{*}=\sqrt{\frac{s_{1} p_{1} Q_{1}}{2\left\{2 k\left(d_{2}-C_{L}\right)+x_{1}\right\}}-\sqrt{\frac{s_{2} p_{2} Q_{2}}{2\left(2 k C_{L}+x_{2}\right)}}} \\
& r^{*}=\sqrt{\frac{s_{2} p_{2} Q_{2}\left\{2 k\left(d_{2}-C_{L}\right)+x_{1}\right\}}{s_{1} p_{1} Q_{1}\left(2 k C_{L}+x_{2}\right)}}
\end{aligned}
$$

$$
S C^{*}=\left(p_{1} Q_{1}+p_{2} Q_{2}\right)
$$$$
+\sqrt{2 s_{1} p_{1} Q_{1}\left\{2 k\left(d_{2}-C_{L}\right)+x_{1}\right\}+2 s_{2} p_{2} Q_{2}\left(2 k C_{L}+x_{2}\right)}
$$

\section{2 買物行動の空間的变化パターン}

以上のように定式化した各地区においての同時購買と 個別購買のトリップ頻度および同時購買率の最適值の関 数式の高次中心地からの距離 $d_{2}$ に関する 1 階と 2 階の 導関数を求め, その性質から消費者の位置 $\left(d_{2}\right)$ によって 買物行動トリップパターンが空間的に異なることを明ら かにすることができる。

(1) 同時購買トリップの空間的変化

式(6)，(10)，(14)の $d_{2}$ について 1 階と 2 階の導関数を求め る。

(1) 地区 I $\left[C_{H}, b_{1}\right]$

$\frac{\partial f_{2}^{*}}{\partial d_{2}}=0$

(2) 地区 II $\left[b_{1}, C_{L}\right]$

$\frac{\partial f_{2}^{*}}{\partial d_{2}}=$

$-\sqrt{\frac{s_{2} p_{2} Q_{2}}{2\left\{2 k\left(2 d_{2}-C_{L}\right)+x_{2}\right\}}} \cdot \frac{k}{2 k\left(2 d_{2}-C_{L}\right)+x_{2}}<0 \quad$ (19a)

$\frac{\partial^{2} f_{2}^{*}}{\partial\left(d_{2}\right)^{2}}>0$

(3) : 地区III $\left[C_{L}, h\right]$

$\frac{\partial f_{2}^{*}}{\partial d_{2}}=0$

（2）個別購買トリップの空間的変化

(1) 地区 I . $\left[C_{H}, \cdot b_{1}\right]$

$$
\begin{aligned}
& \frac{\partial f_{1}^{*}}{\partial d_{2}}=-\sqrt{\frac{s_{1} p_{1} Q_{1}}{2\left(2 k d_{2}+x_{1}\right)}} \cdot \frac{k}{2\left(2 k d_{2}+x_{2}\right)}<0 \\
& \frac{\partial^{2} f_{1}^{*}}{\partial\left(d_{2}\right)^{2}}>0
\end{aligned}
$$

(2) 地区 II $\left[b_{1}, C_{L}\right]$

$$
\begin{aligned}
\frac{\partial f_{1}^{*}}{\partial d_{2}} & =\sqrt{\frac{s_{1} p_{1} Q_{1}}{2\left\{2 k\left(C_{L}-d_{2}\right)+x_{1}\right\}}} \cdot \frac{k}{2\left\{2 k\left(C_{L}-d_{2}\right)+x_{1}\right\}} \\
& +\sqrt{\frac{s_{2} p_{2} Q_{2}}{2\left\{2 k\left(2 d_{2}-C_{L}\right)+x_{2}\right\}}} \cdot \frac{k}{2 k\left(2 d_{2}-C_{L}\right)+x_{2}}>0
\end{aligned}
$$

$\frac{\partial^{2} f_{1}^{*}}{\partial\left(d_{2}\right)^{2}}>0 \quad$ if $\frac{s_{1} p_{1} Q_{1}}{s_{2} p_{2} Q_{2}}>16\left\{\frac{2 k\left(C_{L}-d_{2}\right)+x_{1}}{2 k\left(2 d_{2}-C_{L}\right)+x_{2}}\right\}^{5}$

$\frac{\partial^{2} f_{1}^{*}}{\partial\left(d_{2}\right)^{2}}<0 \quad$ if $\frac{s_{1} p_{1} Q_{1}}{s_{2} p_{2} Q_{2}}<16\left\{\frac{2 k\left(C_{L}-d_{2}\right)+x_{1}}{2 k\left(2 d_{2}-C_{L}\right)+x_{2}}\right\}^{5}$

(3) 地区III $\left[C_{L}, h\right]$

$\frac{\partial f_{1}^{*}}{\partial d_{2}}=$

$-\sqrt{\frac{s_{1} p_{1} Q_{1}}{2\left\{2 k\left(d_{2}-C_{L}\right)+x_{1}\right\}}} \cdot \frac{k}{2\left\{2 k\left(d_{2}-C_{L}\right)+x_{1}\right\}}<0$ (23a)

$\frac{\partial^{2} f_{1}^{*}}{\partial\left(d_{2}\right)^{2}}>0$ 


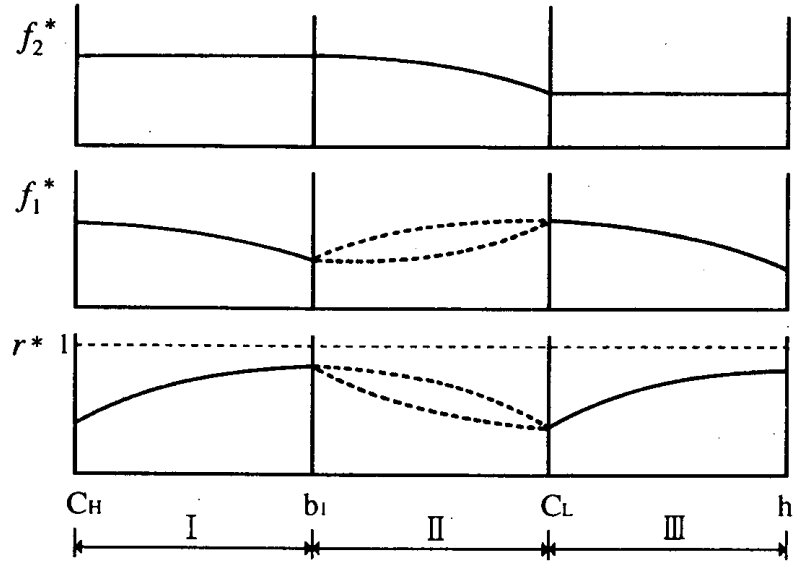

図 2 消費者の空間的買物行動パターン

(3) 同時購買率の空間的変化

(1) 地区 I $\left[C_{H}, b_{1}\right]$

$$
\begin{aligned}
& \frac{\partial r^{*}}{\partial d_{2}}=\frac{1}{2} \sqrt{\frac{s_{2} p_{2} Q_{2}}{s_{1} p_{1} Q_{1}}} \cdot \frac{k}{\sqrt{\left(2 k d_{2}+x_{1}\right) x_{2}}}>0 \\
& \frac{\partial^{2} r^{*}}{\partial\left(d_{2}\right)^{2}}<0
\end{aligned}
$$

(2) 地区 II $\left[b_{1}, C_{L}\right]$

$$
\begin{aligned}
\frac{\partial r^{*}}{\partial d_{2}}= & -\frac{1}{2} \sqrt{\frac{s_{2} p_{2} Q_{2}}{s_{1} p_{1} Q_{1}}} \\
& \left\{\frac{k\left(2 k C_{L}+2 x_{1}+x_{2}\right)}{\sqrt[3]{2 k\left(2 d_{2}+C_{L}\right)+x_{2}} \sqrt{2 k\left(C_{L}-d_{2}\right)+x_{1}}}\right\}<0
\end{aligned}
$$$$
\frac{\partial^{2} r^{*}}{\partial\left(d_{2}\right)^{2}}>0 \text {, if } 14 k C_{L}+6 x_{1}>16 k d_{2}+x_{2}
$$$$
\frac{\partial^{2} r^{*}}{\partial\left(d_{2}\right)^{2}}<0 \text {, if } 14 k C_{L}+6 x_{1}<16 k d_{2}+x_{2}
$$

(3) 地区III $\left[C_{L}, h\right]$

$$
\begin{aligned}
& \frac{\partial r^{*}}{\partial d_{2}}=\frac{1}{2} \sqrt{\frac{s_{2} p_{2} Q_{2}}{s_{1} p_{1} Q_{1}}} \cdot \frac{k}{\sqrt{\left(2 k C_{L}+x_{2}\right)\left(2 k d_{2}+x_{1}\right)}}>0 \\
& \frac{\partial^{2} r^{*}}{\partial\left(d_{2}\right)^{2}}<0
\end{aligned}
$$

以上のことより，消費者の空間的買物行動特性をまと めれば，図 2 のように表すことができる（仮想地域が対 称であるので, 片側のみを示した)。図からもわかるよう に, 消費者の買物行動は中心地の空間的分布に対する消 費者の位置（地区）によって異なるのが明らかである。

\section{4. 同時購買の買物行動と商圈需要}

消費者は買物費用を最小にしようと行動しており，そ れ故に個別購買のみによるトリップパターンではなく， 個別購買と共に同時購買のトリップも行っている。その ような市場環境において，小売施設側は販売額を最大化 することが目的であると仮定すれば，小売業者は相対的 により高い販売額が見込まれるところに参入すると考え
られる。そこで，本章では，高次中心地と低次中心地の 総販売額を同時購買率の関数として導出する。

\section{1 商圈境界}

小売施設（又は中心地）の商圈はある施設が供給して いる財の到達範囲によって決まるが，それは消費者の居 住地を中心にどちらの施設へ行った方が買物費用を最小 にすることができるかの費用最小化行動による施設選択 の分かれ目で，それが施設 (中心地) の商圈境界となる。 そこで，隣接する低次施設の間の商圈境界を消費者の買 物費用関数を用いて定式化することができる。

隣接する 2 つ低次施設 $\left(L_{H}, L_{1}\right)$ 間の商圈境界 $\left(b_{1}\right)$ は，費用最小化の買物行動原則のもとで個別購買の買物 のために，消費者の居住地を中心として左右のどちらの 施設を利用しても負担する費用に差のない地点である。 すなわち，仮想地域（図 I）において地区I と地区IIの 消費者が買物において負担する費用 $S C$ が等しい地点を 求めることとなる。地区 I と地区II の買物費用関数式(9) と(13)を用いて，次のような関係式で表すことができる。

$$
\begin{aligned}
\sqrt{2 s_{1} p_{1} Q_{1} t_{1}^{\mathrm{I}}}+ & \sqrt{2 s_{2} p_{2} Q_{2}\left(t_{2}-t_{1}^{\mathrm{I}}\right)} \\
= & \sqrt{2 s_{1} p_{1} Q_{1} t_{1}^{\mathrm{II}}}+\sqrt{2 s_{2} p_{2} Q_{2}\left(t_{2}-t_{1}^{\mathrm{II}}\right)}
\end{aligned}
$$

式(27)においての $t_{1}^{1} ， t_{1}^{11}$ はそれぞれ地区 I， II の消費者 が低次商品の購入のために低次施設へ行うトリップによ る交通費用である。求められる境界点 $b_{1}$ においては高次 中心地への交通費用 $t_{2}$ は全く同じであるので，結果的に 低次商品の購入のための個別購買トリップによる交通費 用だけを考慮すればよい。従って，結局，式(27)において $t_{1}^{\mathrm{I}}=t_{1}^{\mathrm{II}}$ が成り立つことを意味する。地区 I， II における 個別購買トリップの交通費用はそれぞれ $t_{1}^{\mathrm{I}}=2 k b_{1}+x_{1}$, $t_{1}^{\mathrm{II}}=2 k\left(C_{L}-b_{1}\right)+x_{1}$ であり, $t_{1}^{\mathrm{I}}=t_{1}^{\mathrm{II}}$ の関係によって高次 中心地 $C_{H}$ (の低次施設 $\left.L_{H}\right)$ と低次中心地 $C_{L}$ (の低次施 設 $\left.L_{1}\right)$ との商圈境界 $b_{1}$ は, 次のように求められる。

$$
2 k b_{1}+x_{1}=2 k\left(C_{L}-b_{1}\right)+x_{1}
$$$$
b_{1}=\frac{C_{L}}{2}
$$

\section{2 商圈需要（総販売額）}

高次中心地に立地している低次施設の本来の商圈は $2\left[C_{H}, b_{1}\right]$ である。しかし, 消費者の同時購買の買物行動 により, 低次中心地の商圈の消費者の低次商品需要量の 中で $r^{*}$ (同時購買率) 7)分が高次中心地の低次施設に流出 するので, 高次中心地の低次施設の実質的な商圏は $2\left[C_{H}, h\right]$ となり，その施設にとっては同時購買の買物行 動により商圏が拡大されることとなる。

以上の論理に基づけば, 高次中心地の低次施設は, 地 区I の消費者にはある一定期間中の低次商品の全需要量 を供給し，地区II，IIIの消費者には彼らの低次商品需要 量の $r^{*}$ 分を供給することとなる。従って, 高次中心地の 低次施設 $\left(L_{H}\right)$ の販売額 $\left(S_{L_{H}}\right)$ は, 次のようになる。 


$$
S_{L_{H}}=2 \rho p_{1} Q_{1}\left\{\int_{0}^{b_{1}} d d_{2}+\int_{b_{1}}^{c_{L}} r^{*} d d_{2}+\int_{C_{L}}^{h} r^{*} d d_{2}\right\}
$$

低次中心地 $C_{L}$ に立地している低次施設 $L_{1}$ は, 地区 II とIIIの消費者が個別購買トリップによって購入する低次 商品需要量のみを供給することとなる。すなわち，地区 II, IIIの消費者は高次中心地で高次商品を購入する際, 低 次施設 $\left(L_{H}\right)$ から $r^{*} Q_{1}$ 単位の低次商品を同時購大寸る。 それゆえに，地区II，IIIの消費者の一定期間中の低次商 品需要量 $Q_{1}$ の中で $r^{*}$ 分は高次中心地の低次施設へ流 出し, $\left(1-r^{*}\right)$ 分が低次中心地 (の低次施設) に吸収さ れる。そのようなことから，低次中心地の低次施設 $\left(L_{1}\right)$ の販売額 $\left(S_{L_{1}}\right)$ は次のように定式化することができる。

$$
S_{L_{1}}=\rho p_{1} Q_{1}\left\{\int_{b_{1}}^{c_{L}}\left(1-r^{*}\right) d d_{2}+\int_{c_{L}}^{h}\left(1-r^{*}\right) d d_{2}\right\}
$$

従って，消費者の同時購買の買物行動により低次中心 地にとっては自商圈から幾分かの販売額が流出し, 高次 中心地は周辺低次中心地の商圈からそれだけの販売額を 吸収することとなる。もし，両中心地共に一つの低次施 設が立地しており，かつ諸費用（地価・可変費用・固定 費用など）に地域差がないとすれば，高次中心地の低次 施設は低次中心地の低次施設に比べて超過利潤を得るよ うになる。それ故に高次中心地には消費者の同時購買の 買物行動により，高次と低次商品を共に販売する大規 模施設(デパートや轾合スーパ等)が現れると考之られる。

\section{$\mathrm{C} L=5$ の場合}

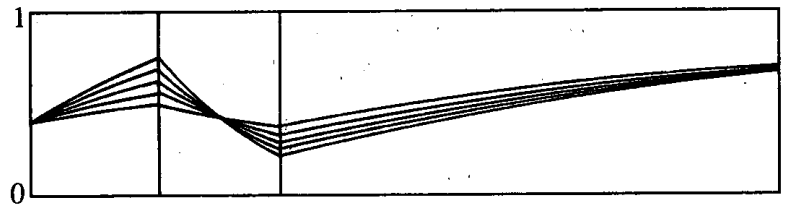

$\mathrm{CL}_{\mathrm{L}}=7.5$ の場合

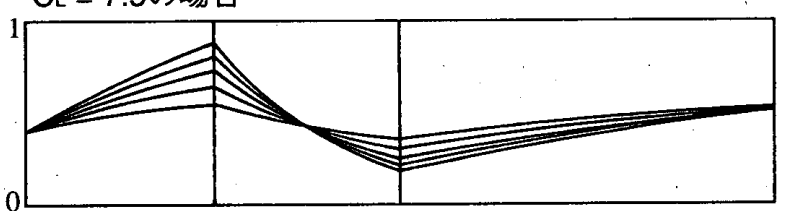

$C_{L}=10$ の場合

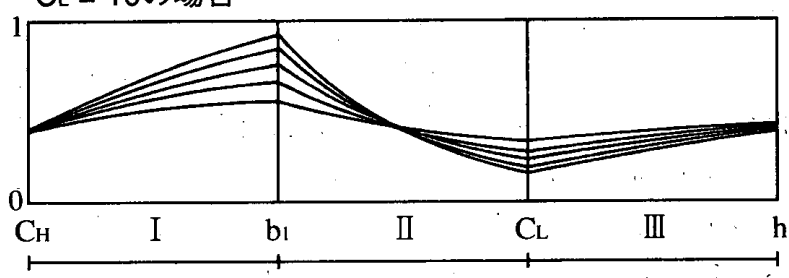

図 3 単位移動費用変化と同時購嘪率の変化パターン

注） $p_{1} Q_{1}=p_{2} Q_{2}=1000, s_{1}=0.1, s_{2}=0.05$ を想定した。 $k$ に 対応するのは地区.Iにおいて下から1,2,3４,5である。

\section{5. 数值シミュレーション}

消費者の買物行動は消費者側の要因の変化と共に変化 している。そこで,「同時購買買物行動モデル」において 単位距離当たり移動費用と単位貯蔵費用を変化させるこ とにより，消費者の買物行動が施設の立地行動にどのよ うな影響を与え，その結果としての空間構造はどのよう なものになるかをより明瞭に示すために数值シミュレー ションを行う。

ここでは, 自動車交通に依存する地方都市圈を想定し, $p_{1} Q_{1}=p_{2} Q_{2}=1000$ 円 $, h=15 \mathrm{~km}, \rho=100$ 人 $/ \mathrm{km}, x_{1}=10$ 円， $x_{2}=15$ 円を設定する。単位距離移動費用 $(k)$ と単位 貯蔵費用 $\left(s_{1}\right)$ はその影響を考察するために， $k$ を $5 \sim 1$ 円 $/ \mathrm{km}\left(s_{1}=0.1 ， s_{2}=0.05\right.$ に固定 $) \frown ， s_{1} を 0.2 \sim 0.08 /$ 期間 $\left(s_{2}=0.05, k=3\right.$ に固定) へそれぞれ低下させる。 また，消費者の買物行動は目的地の構成によって異なり， それによって施設が受ける影響も違って来るので，高次 中心地加の低次中心地の位置を $C_{L}=5,7.5,10 \mathrm{~km}$ に 変化させ，それぞれの状況に扔いて販売額を計算する。

\section{1 消費者の買物行動の数值シミュレーション}

ここでは，買物費用を最小にするために行った行動の 結果である個別購買と同時購買の最適トリップ頻度 $\left(f_{1}^{*}, f_{2}^{*}\right)$ によって定義される同時購買率 $\left(r^{*}\right)$ のケース ごとの空間的変化を考察する。図 $3 ， 4$ はその結果を示 している (具体的数值は表 1,2 参照)。

空間的には高次中心地からの距離 $\left(d_{2}\right)$ の增加と共に, $r^{*}$ は地区I，IIIにおいては增加しているが，地区IIでは

$\mathrm{C} L=5$ の場合

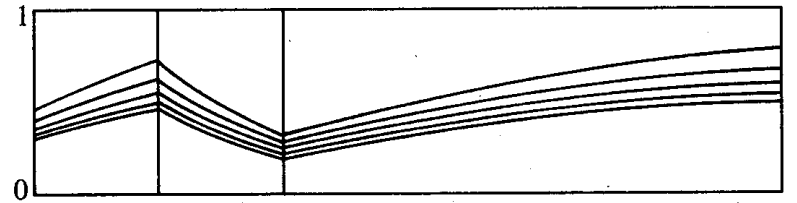

$\dot{C} L=7.5$ の場合

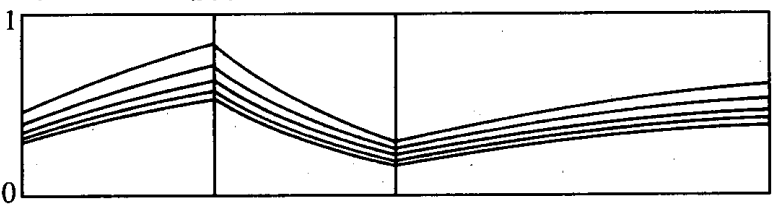

$C L=100$ 場合

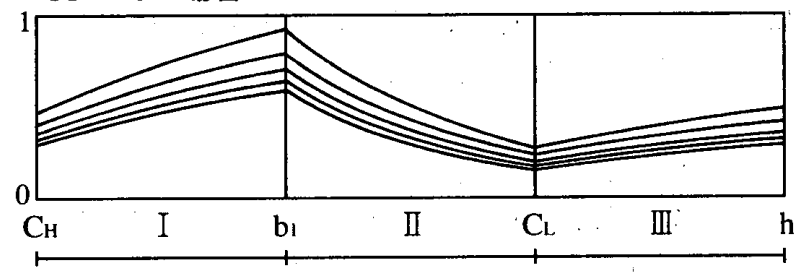

図 4 貯蔵費用変化と同時購買率の変化パターン

注） $k=3, p_{1} Q_{1}=p_{2} Q_{2}=1000, s_{2}=0.05$ を想定した。 $s_{1}$ に対 応寸るのは地区 I において下から0.20,0.17,0.14,0.11， 0.08 である。 
減少している。一方, 単位移動費用 $(k)$ の低下に従い, 地区 I では減少しているが, 低次中心地の商圈である地 区II, IIIでは増加している。これに対し, 低次商品の単 位貯蔵費用 $\left(s_{1}\right)$ を変化させた場合は, それの低下に従い いずれの地区においても一段と増加している。特に， $k$, $s_{1}$ の低下に従い地区IIIの同時購買率の増加が目立つ。

以上のように, 消費者の買物行動は単位移動費用・単 位貯蔵費用の消費者側の要因の変化に従って変化するこ とが数值シミュレーションによって示された。

\section{2 小売施設空間構造の数值シミュレーション}

小売施設 (小売業者) は，基本的には相対的により多 い販売額が見込まれる所に参入すると考えられるので, 同時購買の買物行動環境において高次と低次中心地（の 低次施設）が得る販売額を計算することにより，小売施 設の立地行動と施設集積量（販売額）を考察する。

表 1 は単位距離移動費用 $(k)$ の変化が小売施設 (特に $C_{L}$ に立地している低次施設）の立地行動に及ぼす影響 を示している。 $k$ の低下に従い低次中心地の商圈内の同 時購買率が増加している。すなわち, 交通条件の改善(道 路網整備・自家用車普及率の増加など）による単位移動 費用の低下は低次中心地の商圈から高次中心地への販売 額の流出増加をもたらすので, 高次中心地への小売施設 の新規参入または規模拡張が現れる。

また, 低次中心地が得る販売額を比較して見ると, 適 正の商圈の大きさを確保しながら商圈内の同時購買率を 抑之ることができる $C_{L}=7.5$ の場合が最も多い。これに 対し, $C_{L}=5$ の場合は, 高次中心地に近付いて立地し一 番広い商圈を確保することはできるが, 商圈内の同時購 買率が一段と高くなるので(特に地区III), 販売額が最も 少ない。従って，同時購買の買物行動環境 において, 低次施設のみの低次中心地 $\left(C_{L}\right)$ は, 同時購買率を減少させるために高次中 心地（高次と低次施設の集積地）からある 程度離れて立地する。

一方，表 2 は，高次商品の単位貯蔵費用 $\left(s_{2}\right)$ に比べ低次商品の単位貯蔵費用 $\left(s_{1}\right)$ の相対的な低下が小売施設におよぼす影響 を表している。 $s_{1}$ の低下 $\left(s_{2}=0.05, k=3\right.$ に 固定）に従い同時購買率が増加している。 低次商品の単位貯蔵費用が高い場合 $\left(s_{1}=\right.$ $0.2)$ には, 低次中心地 $\left(C_{L}\right)$ が高次中心地 $\left(C_{H}\right)$ に近接立地している $C_{L}=5$ の販売額 が最も多いが, $s_{1}=0.17$ からは $C_{L}=7.5$ の 場合が最も多くなった。そして， $S_{1}=0.11$ からは商圈が一番広い $C_{L}=5$ の販売額は, 商圈が一番狭い $C_{L}=10$ よりも少ない。

以上の上うなことを考之併せると，低次 中心地に立地している低次施設 $L_{1}$ が高次
中心地に近付いて立地することにより商圈の大きさを拡 大することはできるが, 商圈内の同時購買率が一段と高 くなるので，それは，結局，商圏の大きさの縮小と同じ 結果（またはそれ以上の逆効果）をもたらす。同時購買 率と商圈の大きさというこの 2 つの効果の均衡の取れる ところが, 販売額を最大にすることができる低次施設 $L_{1}$ の最適立地点となる。

一方，消費者の同時購買の買物行動により，結果的に 低次中心地の商圏から幾分かの販売額が流出し，高次中 心地は周辺低次中心地の商圈から販売額を吸収する関係 がある。それ故に，両中心地の施設集積量には格差があ $\eta$ ，商業中心地の階層的空間構造が形成される。それの 形成メカニズムは以下のような論理によって説明するこ とができよう。

単位距離当たり移動費用の低下，あるいは高次商品に 比べ低次商品の単位貯蔵費用の相対的低下があるとすれ ば，同時購買率は増加するので(表 $1 ， 2$ 参照)，低次中 心地の販売額は減少するようになる（これは撤退と出店 低調をもたらす)。しかし，表 $3 ， 4$ に示されているよう に，高次中心地にとってはさらに多い販売額が見込まれ るので, 高次中心地には低次施設の新規参入により小売 施設の集積量は増加すると考えられる（表 3，4の右側 の(3)/(1)，(4)/(2)は高次中心地と低次中心地の販売額の対 比であり，施設集積量の格差として見なせる）。高次中心 地の低次施設が得る販売額が低次施設の成立間值を上回 る限り，高次中心地への低次施設の新規参入は続くだろ j。

茨城県におけるパネルデー夕を用いた実証研究（孫・ 谷村，1995）によれば，中・大規模店の参入による競争

表 1 単位移動費用変化による低次中心地の販売額

\begin{tabular}{|c|c|c|c|c|c|c|c|c|c|}
\hline \multirow[b]{3}{*}{ (円 $/ \mathrm{km})$} & \multicolumn{2}{|c|}{ 同 時 } & \multicolumn{2}{|c|}{ 寺 購 $\quad$ 買 } & \multicolumn{2}{|c|}{ 率 （r*） } & \multicolumn{3}{|c|}{ 低次中心地販売額 (円) (1) } \\
\hline & \multicolumn{2}{|c|}{$C_{L}=5$} & \multicolumn{2}{|c|}{$\mathrm{CL}_{\mathrm{L}}=7.5$} & \multicolumn{2}{|c|}{$C_{L}=10$} & \multirow[t]{2}{*}{$\mathrm{CL}=5$} & \multirow{2}{*}{$\mathrm{CL}_{\mathrm{L}}=7.5$} & \multirow{2}{*}{$\mathrm{CL}_{\mathrm{L}}=10$} \\
\hline & 地区 II & 地区 II & 地区 I & 地区 III & 地区 II & 地区 II & & & \\
\hline 5.0 & 0.522 & 0.585 & 0.545 & 0.485 & 0.557 & 0.373 & 534476 & $35 \times 2$ & 533147 \\
\hline 4.0 & 0.520 & 0.601 & 0.542 & 0.491 & 0.553 & 0.380 & 518960 & 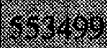 & 583500 \\
\hline 3.0 & 0.519 & 0.617 & 0.540 & 0.498 & 0.549 & 0.391 & 503651 & $(3.80 \%$ & 529919 \\
\hline 2.0 & 0.520 & 0.626 & 0.541 & 0.508 & 0.548 & 0.410 & 493537 & 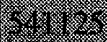 & 520938 \\
\hline 1.0 & 0.525 & 0.635 & 0.540 & 0.523 & 0.552 & 0.437 & 483537 & 30021 & 505499 \\
\hline
\end{tabular}

表 2 眝蔵費用変化による低次中心地の販売額

\begin{tabular}{|c|c|c|c|c|c|c|c|c|c|}
\hline \multirow[b]{3}{*}{ (/期間) } & \multicolumn{2}{|c|}{ 同 時 } & 寺 & 買 & \multicolumn{2}{|c|}{ 率 ( $\left.\mathrm{r}^{*}\right)$} & \multicolumn{3}{|c|}{ 低次中心地販売額 (円)(2) } \\
\hline & \multicolumn{2}{|c|}{$\mathrm{C}_{\mathrm{L}}=5$} & \multicolumn{2}{|c|}{$\mathrm{CL}_{\mathrm{L}}=7.5$} & \multicolumn{2}{|c|}{$\mathrm{Cl}_{\mathrm{L}}=10$} & \multirow{2}{*}{$\mathrm{Cl}_{\mathrm{L}}=5$} & \multirow{2}{*}{$\mathrm{CL}_{\mathrm{L}}=7.5$} & \multirow{2}{*}{$\mathrm{C}_{\mathrm{L}}=10$} \\
\hline & 地区 I & 地区 III & 地区口 & 地区 II & 地区～ & 地区 III & & & \\
\hline 0.20 & 0.364 & 0.434 & 0.373 & 0.347 & 0.379 & 0.275 & 12000 & 724920 & 672914 \\
\hline 0.17 & 0.396 & 0.472 & 0.404 & 0.375 & 0.411 & 0.298 & 678779 & & 645225 \\
\hline 0.14 & 0.437 & 0.520 & 0.445 & 0.413 & 0.453 & 0.329 & 620545 & & 609057 \\
\hline 0.11 & 0.493 & 0.587 & 0.502 & 0.466 & 0.511 & 0.371 & 539878 & 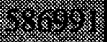 & 558956 \\
\hline 0.08 & 0.578 & 0.688 & 0.589 & 0.547 & 0.599 & 0.435 & 417309 & 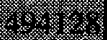 & 482842 \\
\hline
\end{tabular}


表 3 単位移動費用変化による高次中心地の販売額

\begin{tabular}{c|c|c|c|c|c|c}
\hline $\mathrm{k}$ & \multicolumn{2}{|c|}{ 次中心地低次施設販売額 (円) (3) } & \multicolumn{3}{|c}{ (3) / (1) } \\
\cline { 2 - 7 }$($ 円 $/ \mathrm{km})$ & $\mathrm{CL}_{\mathrm{L}}=5$ & $\mathrm{C}_{\mathrm{L}}=7.5$ & $\mathrm{C}_{\mathrm{L}}=10$ & $\mathrm{C}_{\mathrm{L}}=5$ & $\mathrm{C}_{\mathrm{L}}=7.5$ & $\mathrm{C}_{\mathrm{L}}=10$ \\
\hline 5.0 & 1931048 & 1885956 & 1929706 & 3.6 & 3.4 & 3.6 \\
4.0 & 1962080 & 1893002 & 1933000 & 3.8 & 3.4 & 3.6 \\
3.0 & 1992698 & 1902018 & 1940162 & 4.0 & 3.5 & 3.7 \\
2.0 & 2012926 & 1917750 & 1958003 & 4.1 & 3.5 & 3.8 \\
1.0 & 2032926 & 1939500 & 1989001 & 4.2 & 3.7 & 3.9 \\
\hline
\end{tabular}

表 4 貯蔵費用変化による高次中心地の販売額

\begin{tabular}{c|c|c|c|c|c|c}
\hline $\mathrm{S}_{1}$ & \multicolumn{2}{c}{ 高次中心地低次施設販売額(円) (4) } & \multicolumn{3}{|c}{ (4) / (2) } \\
\cline { 2 - 7 }$(/$ 期間) & $\mathrm{CL}_{\mathrm{L}}=5$ & $\mathrm{CL}_{\mathrm{L}}=7.5$ & $\mathrm{CL}_{\mathrm{L}}=10$ & $\mathrm{CL}_{\mathrm{L}}=5$ & $\mathrm{CL}=7.5$ & $\mathrm{CL}=10$ \\
\hline 0.20 & 1549879 & 1550160 & 1654172 & 2.1 & 2.1 & 2.5 \\
0.17 & 1642443 & 1615548 & 1709550 & 2.4 & 2.3 & 2.6 \\
0.14 & 1758910 & 1703788 & 1781886 & 2.8 & 2.6 & 2.9 \\
0.11 & 1920244 & 1826018 & 1882088 & 3.6 & 3.1 & 3.4 \\
0.08 & 2165382 & 2011744 & 2034116 & 5.2 & 4.1 & 4.2 \\
\hline
\end{tabular}

注) 表3,4の(3)/(1), (4)/(2)は表1,2と表3,4の販売頡の対比である。

環境の激化のため，小規模施設の撤退と出店低調により 経年的に商店数の集積量が減少したことが明らかにされ ている。本モデルの結果から，この間に同時購買の買物 行動（同時購買率）が增加したと推論することができよ j。

\section{6.まとめ}

消費者と施設側は互いに影響を及ぼしているが，小売 施設成立の消費者優位性を考えると，基本的には施設側 の変化は消費者の買物行動とその変化の影響を強く受け ると考えられる。消費者は買物費用を節約するために， 個別購買のみのトリップパターンではなく，同時購買ト リップも行っており，その一連の行動は中心地の空間的 分布に対する消費者の位置によって異なると考え，同時 購買の買物行動環境において小売施設の立地行動と空間 構造を理論的に分析した結果，以下のことが明らかに なった。

(1) 消費者の買物行動は交通環境条件の改善により移動 費用が低下するとともに移動性が向上し，高次商品の 単位貯蔵費用に比べ低次商品のそれが相対的に低くな ると，同時購買率は増加する。

(2) 同時購買率を減少させるためには, 商圈の大きさを 犠牲にしても低次施設のみの低次中心地 $\left(C_{L}\right)$ は外方 移動し, 高次中心地 $\left(C_{H}\right.$, 高次施設と低次施設の集積 地) から離れる方が販壳額を増加させることができる。 同時購買率と商圈の大きさというこの $2 つ の$ 効果のト レード・オフにより，販売額が最大になるところが低 次施設のみの低次中心地の最適立地点となる。

すなわち, 本研究は, 消費者の買物行動が小売施設側 に与える影響を取り上げ，その結果としての施設立地行 動を理論的に明らかにしようと試みた。今後の課題とし
て以下のことが考えられる。まず, 本研究の理論的枠組 に基づき, 消費者の買物行動側面から施設立地行動に関 する実証研究が求められる。一方，対象空間システムの 多次元化，消費者の所得と時間制約を条件とした効用最 大化モデルの構築，消費者側の費用最小化（或いは効用 最大化）と施設側の利潤最大化による市場均衡アプロー チによる研究などが今後の課題として挙げられる。

注

1）本論文で使われる商品・施設・中心地・トリップに関する 用語を中心地理論の概念に基づき，以下のように表す。商 品には大きく低次商品（最寄品とも呼ばれている）と高次 商品（買回品）に区分することができ，その低次商品を供 給している施設を低次施設（最寄品店とも呼ばれている）, 高次商品を供給しているものを高次施設（買回品店）とす る。低次施設のみが立地している低位レベルの中心地を低 次中心地，低次と高次施設が共に立地しているところを高 次中心地とする。従って，消費者が買物のための 1 回の外 出において低次商品あるいは高次商品のみを購入するト リップを個別購買 (single-purpose shopping) トリップ, 高次中心地から低次と高次商品をまとめて購入するのを同 時購買 (multi-purpose shopping) トリップ（まとめ買い のこと) とする。

2) Hanson (1980) と O'Kelly (1981) の実証研究によれば, 全買物トリップにおいて30 50\%が同時購買トリップであ るとしている。また, 日本においても, 買物に行くと色々 なものをまとめて買うか(同時購筫派)，欲しいもの 1,2 品買うために出掛けることが多いか（個別購買派）に対す る買物行動の調查結果（日経産業消費研究所，1993）によ ると, 年齢と性別に若干の差異はあるものの, 全体的に「同 時購買派」が $20 \%$ 上回っている。施設の立地行動に間接 的に影響を及ばすその他の要因として，通信販売の普及・ ブランド志向・占の接客形態の多様化などが挙げられる。

3）消費者がある期間中に低次商品（牛乳）と高次商品（鞄） を消費するとしよう。ある時, 高次商品の需要が発生しそ れの購入のために高次中心地に行った祭，この機会を生か すためにその中心地の低次施設から低次商品（牛乳）も同 時に買ってくるとしよj。それにより，牛乳を購入するた めに低次中心地へのトリップを行わなくても済むようにな $\eta$ ，その交通費用を高次中心地へのトリップによって併用 できるので，交通費用を節約することができる。このよう に階次の異なる商品を同時購買することによって買物費用 を節約することができることを範囲の経済 (scope economies）の効果という。

4）四 1 の各記号は以下の通りである。 $Q_{1}, Q_{2}$ : 低次商品と高 次商品の需要量, $C_{H}, C_{L}$ : 高次中心地々低次中心地, $H$ : 高次施設, $L_{H}, L_{1}$ : 高次中心地と低次中心地の低次施設, $h:$ 高次中心地の高次施設の商圈境界, $b_{1}$ : 高次中心地と低 次中心地の商圈境界。そして, $b_{1}, C_{L}, h$ は高次中心地 $\left(C_{H}\right)$ を原点 (0) と考え, そこから離れた距離の地点である。な お，本研究は買物費用最小化行動を前提としているので, 本研究で言う「商圈境界」 $b_{1}$ とは，一般に用いられている 二施設の利用率がおのおの $50 \%$ となる地点という意味では ない。

5）貯蔵費用の式は以下のような概念による(下の图参照)。各 消費者はある一定期間（period）に低次商品（1）を $Q_{1}$ 単 


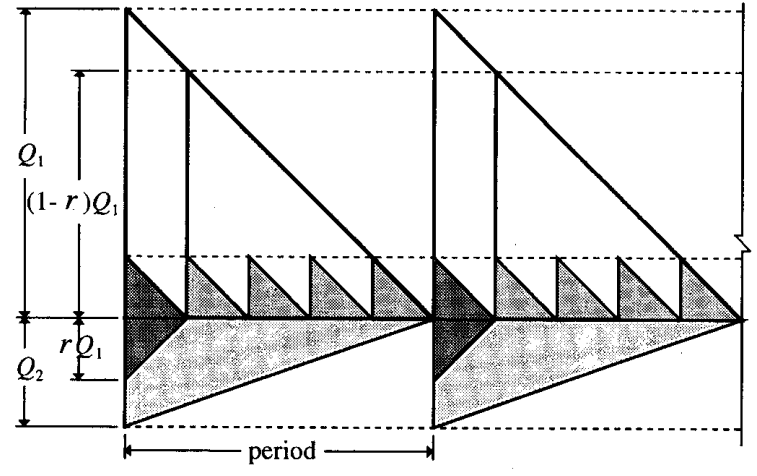

図＼cjkstart消費者の買物パターンと貯蔵費用の考え万

位消費する。その需要量の中で高次中心地への同時購買卜 リップ $f_{2}$ 回に打いて $r Q_{1}$ 単位を購入し, その残り $(1-r) Q_{1}$ 単位を低次中心地への個別購買トリップ $f_{1}$ 回に よって購入する。もし， $(1-r) Q_{1}$ 単位を一回のトリップ (single trip)によって購入したとすれば, 消費者は一定比 率で消費するので, 期間中の平均貯蔵量は $(1-r) Q_{1} / 2 て ゙$, 高次中心地への同時購買トリップの際に購入した単位に对 する平均眝蔵量は $r Q_{1} / 2$ である。これらを頻度を考慮し表 わせば, 各々 $(1-r) Q_{1} / 2 f_{1}, r Q_{1} / 2 f_{2}$ となる。従って, 期 間中の低次商品の全需要量 $Q_{1}$ は $\left\{(1-r) Q_{1}+r Q_{1}\right\}=Q_{1}$ で, 平均貯蔵量は $Q_{1} / 2$ となる。低次商品の需要量 $Q_{1}$ は $\left(f_{1}\right.$ $\left.+f_{2}\right)$ 回トリップによって購入されたので,この頻度を考慮 すれば, 平均貯蔵量は $Q_{1} / 2\left(f_{1}+f_{2}\right)$ となる。低次商品の単位 当たり貯藏費用は $s_{1} p_{1}$ であるので, 消費者が全期間中に負 担寸る低次商品の貯蔵費用は $\left(s_{1} p_{1} Q_{1}\right) / 2\left(f_{1}+f_{2}\right)$ になる。同 様の考之方により, 高次中心地への $f_{2}$ 回トリップから睡入 した高次商品の平均貯蔵量は $Q_{2} / 2 f_{2}$ で, 貯蔵費用は $s_{2} p_{2} Q_{2} / 2 f_{2}$ である。

6) 各地区は各中心地の左右の商圈であるが，その境界線の設 定は 4.1 節を参照されたい。そして, 高次中心地からの距離 $d_{2}$ は地域においての消費者の空間的位置として見なす。

7) 低次中心地 $\left(C_{L}\right)$ 側から見れば，同時購買率 $\left(r^{*}\right)$ は流出 率， $\left(1-r^{*}\right)$ は地元吸収率として考えられる。

\section{参考文献}

1）孫 相洛 - 谷村秀彦, 小売施設立地性向の時系列的分析 一茨城県パネルデータ（1970-91）による分析，日本建築学 会計画系論文集 $468 ， p p .95-102 ， 1995$ 。

2）日経産業消費研究所，消費者の百貨店観と利用実態，日本 経済新聞杜, pp.9-13，1993。

3）森川 洋, 中心地研究：理論・研究動向および実証，大明 堂, pp.279-319, 1974。

4）林上，中心地理論研究，大明堂，pp.531-564，1986。

5) Bacon, R.W., Consumer Spatial Behavior: A model of purchasing decisions over space and time, Oxford Univ. press, 1984.

6) Eaton, B.C., and Lipsey, R.G., Comparsion Shopping and the Clustering of Homogeneous Firms, Journal of Regional Science 19, pp.421-435, 1979.

7) Eaton, B.C., and Lipsey, R.G., An Economic Theory of Central Places, The Economic journal 92, pp.56-72, 1982.

8) Hanson, S., Spatial Diversification and Multipurpose Travel: Implications for Choice Theory, Geographical Analysis 12, pp.245-257, 1980.

9) Hotelling, H., Stability in Competition, Economic Journal 29, pp.41-57, 1929.

10) O'Kelly, M., A Model of the Demand for Retail Facilities Incorporating Multistop, Multipurpose Trips, Geographical Analysis 13, pp.134-148, 1981.

11) Thill, L.C., Spatial Duopolistic Competition with Multipurpose and Multistop Shopping, Annals of Regional Science 26, pp.287-304, 1992.

（1995年 2 月 10 日原稿受理，1996年 3 月 26 日採用決定） 